\title{
Study the Effect of Different Levels of Protein and Energy Diet on the Growth, Performance and Economics of Cross Bred (T\&D) Piglets Reared in Godda District of Jharkhand, India
}

\author{
Satish Kumar ${ }^{1}$, Neeraj ${ }^{1}$ and S. Shekhar ${ }^{2 *}$ \\ ${ }^{1}$ Sundaresan School Of Animal Husbandry and Dairying, Sam Higginbottom University of \\ Agriculture, Technology and Sciences, Allahabad, U.P., India \\ ${ }^{2}$ Krishi Vigyan Kendra (ICAR-NRRI), Jainagar, Koderma, Jharkhand-825324, India \\ *Corresponding author
}

\section{A B S T R A C T}

\begin{tabular}{|l|}
\hline K e y w o r d s \\
$\begin{array}{l}\text { Body weight, Feed } \\
\text { efficiency, Economics, } \\
\text { Energy diet, Protein } \\
\text { diet }\end{array}$ \\
\hline Article Info \\
\hline $\begin{array}{l}\text { Accepted: } \\
\text { 12 December } 2017 \\
\text { Available Online: } \\
\text { 10 January } 2018\end{array}$ \\
\hline
\end{tabular}

\section{Introduction}

Pigs being the most prolific and efficient meat producing animals are very popular among the poor people of the society with tribals of Jharkhand state (Kumar et al., 2008). Pig rearing is one of the most important occupations of rural society especially the tribal masses of India. In India, there is an overall shortage of energy and protein rich feeds and consequently they are costly
Pig has a great potential to contribute to better economic return to the farmers. A balanced diet having proper ratio of energy and protein need to be prepared to make the pig farming economical. The present study was carried out on over 30 growing three months old crossbred piglets to evaluate the energy and protein requirement in growing and finishing pigs. Accordingly, five diets were prepared viz. $\mathrm{T}_{1}$ (Medium energy (75\%) and medium protein diet $(18 \%) ; \mathrm{T}_{2}$ (Medium energy (75\%) and low protein diet $(16.20) ; \mathrm{T}_{3}$ (Low energy $(67.50 \%)$ and high protein diet $(19.80 \%)$; $\mathrm{T}_{4}$ (Low energy $(67.50 \%)$ and medium protein diet $(18 \%)$ and $\mathrm{T}_{5}$ (Low energy $(67.50 \%)$ and Low protein diet $(16.20 \%)$. The average daily body weight gains, feed efficiency in the piglets fed on different experimental groups was calculated. Differences among the groups were observed to be statistically non-significant, yet the rate of gains decreased with decrease of energy and protein levels in their rations notably in the $\mathrm{T}_{5}$ group. Similarly, cost per kilo gram edible meat was observed to lowest in $\mathrm{T}_{1}$ (93.68Rs.), followed by $\mathrm{T}_{2}\left(95.87 \mathrm{Rs}\right.$.), $\mathrm{T}_{3}\left(97.91 \mathrm{Rs}\right.$.), $\mathrm{T}_{4}$ (98.61 Rs.), and $\mathrm{T}_{5}$ (98.61 Rs.), respectively. The differences in costs incurred on one $\mathrm{kg}$ gain in body weight were found to be statistically non- significant. 
balanced diet with ratio of energy and protein need to be prepared to make the pig farming economical. It have been demonstrated that lowering the protein level of feed reduces the energy losses in urine and as heat (Noblet et al., 1987 and Quiniou et al., 1996). The objectives of the current experiment were to determine the effect of various levels of protein and energy based diet at on the growth, performance and economics of cross bred $(T \& D)$ piglet reared in Godda district of Jharkhand.

\section{Materials and Methods}

Present experiment was carried out at pig breeding farm of G.V.T. - Krishi Vigyan Kendra, Godda, Jharkhand. Thirty (30) weaned cross breed (T\&D) piglets of about three months of age were divided according to their body weight in five groups namely $T_{1}$, $T_{2}, T_{3}, T_{4}$ and $T_{5}$. Each groups consisting of 6 piglets. Piglets of each group were reared separately in separate house. All the piglets were examine for all anti-mortem examination and dewormed before offering the treatment diets (Table 1). The chemical composition of nutrients and vitamin contents of all the ingredients were analyzed. Crude protein and ash \% were analyzed by (AOAC, 1995), crude fat (AOAC, 2000), crude fiber and carbohydrate (AOAC, 2012). Statistical analysis of the data was carried out as per the methods of (Snedecor and Cochran 1994).

\section{Results and Discussion}

The average daily body weight gains in the piglets fed on different experimental groups were calculated. Differences among the groups were observed to be statistically nonsignificant, yet the rate of gains decreased with decrease of energy and protein levels in their rations notably in the $5^{\text {th }}$ group. However, the effect of dietary treatment on live weight, food intake, average 858 to 944 gm daily weight gains (ADG) and food conversion FCR were reported by Carpenter et al., (2004) and Noblet et al., (2001) 858 to $944 \mathrm{gm}$ in large white and landrace crossbred with faded dietary protein concentration as 122.5 to 207.5. Compared to the present studies higher daily weight gains were obtained in growing cross-bred piglets by many workers viz. 626 to 691g (Ewan, 1989) who fed rations containing maize cob in the ratio of $1: 1,660$ to $659 \mathrm{~g}$ (Kyriazakis and Emmans, 1992) who added pelleted cassava from 30 to $70 \%$ in the ration of piglets, 561 to 528 g (Hoffman, et al., 1992) who replaced basal feed mixture with 3 to $5 \%$ rape seed meal, 832 to $547 \mathrm{~g}$ by (Campbell, and Dunkin; 1983) who replaced maize with deoiled rice bran from 20 to $80 \%$ with ration, 539 to $530 \mathrm{~g}$ by (Close, 1994) who studied the effect of keeping pigs in pen/battery on normal concentrate mixture. The growth of piglets in the present study is considered to be satisfactory. Overall, the daily gain recorded in the present studies in a span of 23 weeks was also considered to be satisfactory. The feed efficiency ratio of experimental groups $T_{1}$ to $\mathrm{T}_{5}$ has been calculated to be $4.17 \pm 0.12: 1$, $4.38 \pm 0.16: 1,4.36 \pm 0.20: 1,4.42 \pm 0.19: 1$ and $4.37 \pm 0.22: 1$ respectively, in the present experiment (Table 4). Differences among the groups were non - significant indicating that all the five rations were equally efficient.

The feed efficiency ratios obtained in the present study were higher when compared to the results of many workers who obtained feed efficiency ratios varying from 4.65 to 7.70 in crossbred pigs when they fed either standard ration or rations containing various levels of different by-products (Morgan, et al., 1975; Nehring and Haenlein, 1973 and Noblet, et al., 1987). However, the feed efficiency ratio obtained in the present studies is in close agreement with those of 3.78 to 4.16 (13) who added 40 to $70 \%$ wheat bran in the rations of middle white Yorkshire piglets. 
Table.1 Different level of energy and protein diet fed to different groups of piglets

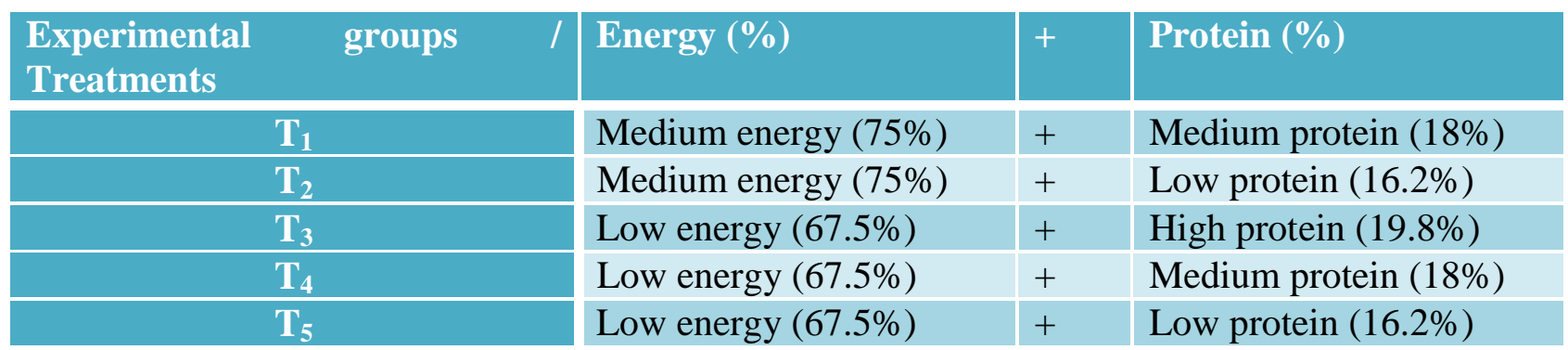

Table.2 Different ingredients and proportions of concentrate mixture used in different experimental groups

\begin{tabular}{l} 
Ingredients \\
Maize grain (crushed) 10,80 (Parts \\
/100Kg) \\
\hline Ground nut cake (Decorticated) 40, \\
75 (Parts /100Kg) \\
\hline Wheat brain 12,65(Parts /100Kg) \\
\hline Fish meal 40,60(Parts /100Kg) \\
\hline Mineral mixture (Parts /100Kg) \\
\hline common salt(Parts /100Kg) \\
\hline Total \\
\hline Vitamin supplements (g / 100Kg) \\
\hline CP \% (calculated) \\
\hline TDN \% \\
\hline DE(Kcal / Kg) (calculated) \\
\hline
\end{tabular}

\begin{tabular}{|l|l|l|l|l|}
\hline $\mathrm{GT}_{1}$ & $\mathrm{GT}_{2}$ & $\mathrm{GT}_{3}$ & $\mathrm{GT}_{4}$ & $\mathrm{GT}_{5}$ \\
\hline 62.00 & 65.50 & 18.00 & 45.00 & 32.00 \\
\hline 20.00 & 14.50 & 24.00 & 20.00 & 12.00 \\
\hline 10.00 & 12.00 & 50.00 & 27.00 & 48.00 \\
\hline 6.00 & 6.00 & 6.00 & 6.00 & 6.00 \\
\hline 1.50 & 1.50 & 1.50 & 1.50 & 1.50 \\
\hline 0.50 & 0.50 & 0.50 & 0.50 & 0.50 \\
\hline $\mathbf{1 0 0}$ & $\mathbf{1 0 0}$ & $\mathbf{1 0 0}$ & $\mathbf{1 0 0}$ & $\mathbf{1 0 0}$ \\
\hline 20.00 & 20.00 & 20.00 & 20.00 & 20.00 \\
\hline 17.80 & 16.19 & 19.89 & 17.94 & 16.16 \\
\hline 74.7 & 74.18 & 68.50 & 68.40 & 69.40 \\
\hline 3200 & 3150 & 3120 & 3100 & 3220 \\
\hline
\end{tabular}

Table.3 Average weekly body weight of the experimental piglets (kg.)

\begin{tabular}{|c|c|c|c|c|c|c|c|}
\hline Period (weekly) & $\mathrm{T}_{1}$ & $\mathbf{T}_{2}$ & $\mathbf{T}_{3}$ & $\mathbf{T}_{4}$ & $\mathbf{T}_{5}$ & $\mathbf{F}$ & CD \\
\hline Initial & $\begin{array}{l}16.91 \pm \\
0.60\end{array}$ & $\begin{array}{l}16.91 \\
\pm .72\end{array}$ & $\begin{array}{l}16.92 \pm \\
0.56\end{array}$ & $17.00 \pm 0.52$ & $16.83 \pm \mathbf{0 . 8 0}$ & 1.21 & NS* \\
\hline $8^{\text {th }}$ & $\begin{array}{l}37.50 \pm \\
2.50\end{array}$ & $\begin{array}{l}36.08 \pm \\
2.10\end{array}$ & $\begin{array}{l}35.58 \pm \\
2.12\end{array}$ & $35.58 \pm 2.02$ & $33.58 \pm 2.23$ & 0.82 & NS* \\
\hline $16^{\text {th }}$ & $\begin{array}{l}58.58 \pm \\
4.20\end{array}$ & $\begin{array}{l}54.50 \pm \\
3.50\end{array}$ & $\begin{array}{l}53.58 \pm \\
3.6\end{array}$ & $56.25 \pm 3.70$ & $54.92 \pm 3.40$ & 1.64 & NS* \\
\hline $23^{\text {th }}$ & $\begin{array}{l}79.25 \pm \\
7.45\end{array}$ & $\begin{array}{l}76.33 \pm \\
6.89\end{array}$ & $\begin{array}{l}76.80 \pm \\
6.78\end{array}$ & $76.58 \pm 5.87$ & $76.67 \pm 5.69$ & 1.04 & NS* \\
\hline $\begin{array}{l}\text { Total gain in } \\
23^{\text {th }} \text { week }\end{array}$ & $\begin{array}{l}62.33 \pm \\
6.28\end{array}$ & $\begin{array}{l}59.42 \pm \\
5.44\end{array}$ & $\begin{array}{l}59.88 \pm \\
5.68\end{array}$ & $59.67 \pm 5.22$ & $59.73 \pm 5.02$ & 1.24 & NS* \\
\hline $\begin{array}{l}\text { AVERAGE } \\
\text { GAIN/WEEK }\end{array}$ & $\begin{array}{l}2.72 \pm \\
0.59\end{array}$ & $\begin{array}{l}2.58 \pm \\
0.46\end{array}$ & $\begin{array}{l}2.61 \pm \\
0.53\end{array}$ & $2.62 \pm 0.21$ & $2.60 \pm 0.56$ & 1.24 & NS* \\
\hline $\begin{array}{l}\text { AVERAGE DAILY } \\
\text { GAIN (GM) }\end{array}$ & $\begin{array}{l}380.99 \\
\pm 31.09\end{array}$ & $\begin{array}{l}369.07 \\
\pm 29.46\end{array}$ & $\begin{array}{l}371.93 \pm \\
32.61\end{array}$ & $\begin{array}{l}376.27 \pm \\
45.49\end{array}$ & $371.68 \pm 35.25$ & 1.25 & NS* \\
\hline
\end{tabular}

$* \mathrm{NS}=$ Non - Significance at $5 \%$ level. 
Table.4 Average feed efficiency of various rations in cross bred (T D) piglets

\begin{tabular}{|c|c|c|c|c|c|}
\hline \multirow{2}{*}{ Particulars } & \multicolumn{5}{|c|}{ Experimental groups } \\
\hline & $\mathbf{T}_{1}$ & $\mathbf{T}_{2}$ & $\mathbf{T}_{3}$ & $\mathbf{T}_{4}$ & $\mathbf{T}_{5}$ \\
\hline $\begin{array}{l}\text { Feed consumption per } \\
\text { pig (kg) during } \\
\text { experimental period (168 } \\
\text { days on DM basis) } \\
\end{array}$ & 259.66 & 260.24 & 261.24 & 263.98 & 260.87 \\
\hline $\begin{array}{l}\text { Average feed } \\
\text { consumption/ pig/day } \\
\text { (kg) }\end{array}$ & 1.555 & 1.558 & 1.564 & 1.581 & 1.562 \\
\hline $\begin{array}{l}\text { Total weight gain in } 168 \\
\text { days / pigs (kg) }\end{array}$ & $62.33 \pm 6.28$ & $59.42 \pm 5.44$ & $59.88 \pm 5.68$ & $59.67 \pm 5.22$ & $59.73 \pm 5.02$ \\
\hline $\begin{array}{l}\text { Weight } \\
\text { (gm) }\end{array}$ & $380.99 \pm 31.09$ & $369.07 \pm 29.46$ & $371.93 \pm 32.61$ & $376.27 \pm 45.49$ & $371.68 \pm 35.25$ \\
\hline Feed gain ratio & $4.17 \pm \mathbf{0 . 1 2 : 1}$ & $4.38 \pm \mathbf{0 . 1 6 : 1}$ & $4.36 \pm \mathbf{0 . 2 0 : 1}$ & 4.42 $\pm \mathbf{0 . 1 9 : 1}$ & $4.37 \pm \mathbf{0 . 2 2 : 1}$ \\
\hline
\end{tabular}

Table.5 Economics of production of growing Tamworth and Desi pigs fed various types of rations

\begin{tabular}{|c|c|c|c|c|c|c|c|c|c|c|}
\hline \multirow[t]{2}{*}{ Particulars } & \multicolumn{2}{|c|}{ Group $T_{1}$} & \multicolumn{2}{|c|}{ Group $\mathrm{T}_{2}$} & \multicolumn{2}{|c|}{ Group $\mathrm{T}_{3}$} & \multicolumn{2}{|c|}{ Group $\mathrm{T}_{4}$} & \multicolumn{2}{|c|}{ Group $T_{5}$} \\
\hline & $\begin{array}{l}\text { Quantit } \\
\text { y (kg.) }\end{array}$ & $\begin{array}{l}\text { Cost } \\
\text { (Rs.) }\end{array}$ & $\begin{array}{l}\text { Quantit } \\
\text { y (kg.) }\end{array}$ & $\begin{array}{l}\text { Cost } \\
\text { (Rs.) }\end{array}$ & $\begin{array}{l}\text { Quantit } \\
\text { y (kg.) }\end{array}$ & $\begin{array}{l}\text { Cost } \\
\text { (Rs.) }\end{array}$ & $\begin{array}{l}\text { Quantit } \\
\text { y (kg.) }\end{array}$ & $\begin{array}{l}\text { Cost } \\
\text { (Rs.) }\end{array}$ & $\begin{array}{l}\text { Quanti } \\
\text { ty (kg.) }\end{array}$ & $\begin{array}{l}\text { Cost } \\
\text { (Rs.) }\end{array}$ \\
\hline $\begin{array}{l}\text { Consumption } \\
\text { and cost of } \\
\text { concentrate } \\
\text { rations / pig }\end{array}$ & 301.93 & $\begin{array}{c}5839 . \\
33\end{array}$ & 302.61 & $\begin{array}{c}5696 . \\
63\end{array}$ & 303.77 & $\begin{array}{c}5862 . \\
76\end{array}$ & 306.95 & $\begin{array}{c}5884 . \\
23\end{array}$ & 303.33 & $\begin{array}{c}5532.7 \\
4\end{array}$ \\
\hline $\begin{array}{l}\text { Cost of feeding/ } \\
\text { animal / day }\end{array}$ & & 34.76 & & 33.91 & & 34.90 & & 35.03 & & 32.93 \\
\hline $\begin{array}{l}\text { Weight } \\
\text { piglet } \\
\text { (gm.) }\end{array}$ & $\begin{array}{c}380.99 \pm \\
31.09\end{array}$ & & $\begin{array}{l}369.07 \\
\pm 29.46\end{array}$ & & $\begin{array}{l}371.93 \\
\pm 32.61\end{array}$ & & $\begin{array}{l}376.27 \\
\pm 45.49\end{array}$ & & $\begin{array}{l}371.68 \\
\pm 35.25\end{array}$ & \\
\hline Cost/kg gain & & 93.68 & & 95.87 & & 97.91 & & 98.61 & & 92.63 \\
\hline $\begin{array}{l}\text { Cost/kg edible } \\
\text { meat }\end{array}$ & & 124.0 & & 125.5 & & 126.0 & & 128.0 & & 130.00 \\
\hline
\end{tabular}

The feed efficiency ratios recorded in the present studies (4.17 to 4.42) are considered to be highly satisfactory. The prices of ingredients' of complex concentrate mixture which were used in present investigations have been incorporated in (Table 2). The prices of ingredients of complex concentrate mixtures which were used in present investigations have been summarized in
(Table 5). Prices were calculated per $100 \mathrm{~kg}$ feed. Cost (Rs.) per kg body weight gain. The costs of the concentrate mixture fed to $T_{1}, T_{2}$, $\mathrm{T}_{3}, \mathrm{~T}_{4}$ and $\mathrm{T}_{5}$ groups of pigs were 1934.00, $1882.50,1930.00,1917.00$ and 1824.00 per quintal, respectively. The costs of feeding per animal per day were calculated to be to be Rs. 34.76, 33.91, 34.90, 35.03 and 32.93 for the groups $T_{1}, T_{2}, T_{3}, T_{4}$ and $T_{5}$ respectively and 
the costs incurred on one $\mathrm{kg}$ gain in body weight were Rs. 93.68, 95.87, 97.91, 98.61 and 92.63 for the groups $T_{1}$ to $T_{5}$ respectively. The differences in costs incurred on one $\mathrm{kg}$ gain in body weight were found to be statistically non- significant. Similar trend was noted in cost of production by various workers when fed rations containing different agro-industrial by-products to many exotic pig (Campbell, 1987; Morgan. et al., 1975; Nehring and Haenlein, 1973 and Ranjhan et al., 1971).

Pig has a great potential to contribute to better economic return to the farmers. A balanced diet having proper ratio of energy and protein need to be prepared to make the pig farming economical. Average dry matter intake and weekly growth body weight gain were observed to be non-significant among groups (Table 4). The result indicates that different proportion of diet containing different ratio of energy and protein affects growth performance might be due to better utilization of diet having balanced proportion. The differences in costs incurred on one $\mathrm{kg}$ gain in body weight were also found to be statistically non- significant among the treatment groups.

\section{Acknowledgement}

The authors gratefully acknowledge the financial assistance received from Senior Scientist and Head, G.V.T. - KVK, Godda (Jharkhand) and ICAR-ATARI, Zone-II, Kolkata to carry out the work as a research project "Energy and protein requirement in growing and finishing cross- bred (Tamworth $\&$ Desi) pig for optimum performance.

\section{References}

Adesehinwa, A. O. K. and Ogunmodede, B. K. 1995. Swine feeds and practical feed composition techniques, in:
N.A.E.R.L.S. workshop training manual, Moor plantation, Ibadan, (April 3-7, 1995) Nat. pig Prod. pp. 27-56.

AOAC 1995. Official Methods of Analysis, Gaithersburg, Maryland, USA, AOAC International, Association of official Analytical chemistry, $1^{\text {th }}$ Edition.

AOAC 2000. Official Methods of Analysis, Gaithersburg, Maryland, USA, AOAC International, Association of official Analytical chemistry, $17^{\text {th }}$ edn.

AOAC 2012. Official Methods of Analysis, Gaithersburg, Maryland, USA, AOAC International, Association of official Analytical chemistry, $19^{\text {th }}$ edn.

Campbell, R. G. 1987. Energy and protein metabolism in the pig. Pages 85-95 in Manipulating pig production. J. L. Barnett, ed. Australian Pig Science Association, Werribee, Australia.

Campbell, R. G., and A. C. Dunkin. 1983. The influence of dietary protein and energy intake on the performance, body composition and energy utilization of pigs growing from 7 to $19 \mathrm{~kg}$. Animal Production. 36: 185-192.

Carpenter, D. A., O. Mara F. P. and O. Doherty J. V. 2004. The effect of dietary crude protein concentration on growth performance, carcass composition and nitrogen excretion in entire grower - finisher pigs. Irish Journal of Agricultural and food Research. 43: 227-236.

Close, W. H. 1994. Feeding new genotypes: Establishing amino acid/energy requirement. Pages 123-140 in Principles of Pig Science. D. J. A. Cole, J. Wiseman, and M. A. Varley, ed. Nottingham Univ. Press, England.

Ewan, R. C. 1989. Predicting the energy utilization of diets and feed ingredients by pigs. Pages 215-218 in Energy metabolism of farm animals. Y. van der Honing, and W. H. Close, ed. 
Proceedings of the 11th Symposium, Lunteren, The Netherlands.

Hoffman, L., W. Jentsch, and M. Beyer. 1992. The energy metabolism of growing swine in a live weight range of 10-50 kg. 3. Energy maintenance requirement of growing swine. Arch Tierernahr, 42: 235-248.

Kumar, S., Prasad, N. Thakur, S. and Singh, S. K. 2008. Effect of higher levels of zinc on utilization and mineral balance in indigenous pigs. Animal Nutrition and Feed Technology, 8: 285-288.

Kyriazakis, I., and G. C. Emmans. 1992. The effects of varying protein and energy intakes on the growth and body composition of pigs. 1. The effects of energy intake at constant, high protein intake. British Journal of Nutrition, 68: 603-613.

Morgan, D. J., D. J. A. Cole, and D. Lewis. 1975. Energy values in pig nutrition. I. The relationship between digestible energy, metabolizable energy and total digestible nutrient values of a range of feedstuffs. Journal of Agricultural Science, 84: 7-17.

Nehring, K., and G. F. W. Haenlein. 1973. Feed evaluation and ration calculation based on net energy. Journal of Animal Science. 36: 949-964.
Noblet, J. and Le Goff, G. 2001. Effect of dietary fibre on the energy value of feeds for pigs. Animal Feed Science Technology. 90: 35-52.

Noblet, J., Henry, Y. and Dubois, S. 1987. Effect of protein and lysine levels in the diet on body gain composition and energy utilization in growing pigs. Journal of Animal Science, 65: 717-726.

Noblet, J., Henry, Y. and Dubois, S. 1994. Prediction of net energy value of feeds for growing pigs. J. Anim. Sci. 72: 344354.

Quiniou, N., J. Y. Dourmad, and J. Noblet. 1996. Effect of energy intake on the performance of different types of pig from 45 to $100 \mathrm{~kg}$ body weight. 1 . Protein and lipid deposition. Animal Science, 63: 277-288.

Ranjhan, S. K., Gupta, B. S., Chabra, S. S. and Dhudapker, B. S. 1971. Effect of various levels of crude fibre and energy in the rations of growing middle White Yorkshire pigs. Indian journal of animal sciences, 41: 373-376.

Snedecor, G.W. and Cochran, W.G. 1994. Statistical methods.8th edition. Iowa State University Press, Ames, Iowa.

\section{How to cite this article:}

Satish Kumar, Neeraj and Shekhar, S. 2018. Study the Effect of Different Levels of Protein and Energy Diet on the Growth, Performance and Economics of Cross Bred (T\&D) Piglets Reared in Godda District of Jharkhand, India. Int.J.Curr.Microbiol.App.Sci. 7(01): 1379-1384.

doi: https://doi.org/10.20546/ijcmas.2018.701.168 